\title{
Spectral response of temperature and vegetation in regions with an incidence of hotspots in a river basin, case study
}

\author{
Carlos Augusto Alves Cardoso Silva ${ }^{1}$; Kamilla Andrade de Oliveira ${ }^{l}$; Rennato Oliveira da Silva ${ }^{l}$; \\ Ana Karla da Silva Oliveira ${ }^{l}$; Eduardo Arouche da Silva ${ }^{l}$; Maria Patrícia Pereira Castro ${ }^{l}$; \\ Washington da Silva Sousa ${ }^{1}$
}

\footnotetext{
${ }^{1}$ Universidade Federal do Maranhão (UFMA), Maranhão, Brasil

*e-mail: carlosaugusto8435@gmail.com
}

\begin{abstract}
Fires significantly alter the vegetation cover, directly influencing the temperature of the soil surface, with vegetation being a natural regulator of the temperature of the environment. Thus, the objective was to evaluate in areas with higher incidence of hotspots the relationship between soil temperature and the Normalized Difference Vegetation Index (NDVI) of the Itapecuru River watershed, State of Maranhão. The study area is located in the centre-east of the state of Maranhão, between the coordinates $2^{\circ} 51^{\prime}$ to $6^{\circ} 56^{\prime} \mathrm{S}$ and $43^{\circ} 2^{\prime}$ to $43^{\circ} 58^{\prime} \mathrm{W}$ and an area of $52,972.1 \mathrm{~km}^{2}$. The data used in relation to hotspots were obtained from the platform of the Burning Program - INPE, the NOAA12 and ATSR satellites. To calculate the NDVI and soil temperature, scenes from the Landsat satellite, TM/5 sensor were used, with band 4 (near infrared) and band 3 (red) for the NDVI results and band 6 for the calculation of the soil surface temperature. During the period from August 1, 2000 to October 31, 2000, 794 hotspots were detected in the basin area, being distributed: $336,314,154,76$ and 32 hotspots in areas of $25,488.804 \mathrm{~km}^{2}$, $22,622.331 \mathrm{~km}^{2}, 2,162.415 \mathrm{~km}^{2}, 2,236.902 \mathrm{~km}^{2}$ and $461.648 \mathrm{~km}^{2}$, respectively. The NDVI of the total area was calculated and ranged from 0.976 (high vegetation index) to -0.896 (low vegetation index). In $39.28 \%$ of the total area, the highest vegetation indices were registered, with values between 0.976 and 0.47 . While in $0.4058 \%$, the lowest indexes were found, between -0.184 and $-0,896$. In relation to temperature, values ranging from $10^{\circ} \mathrm{C}$ to $15^{\circ} \mathrm{C}$ were found for lower temperatures and $26^{\circ} \mathrm{C}$ to $39^{\circ} \mathrm{C}$ for higher temperatures, corresponding to $0.8462 \%$ and $38.631 \%$, respectively, of the total area, highlighting temperatures between 22.2 and $26.3^{\circ} \mathrm{C}$ in $53.25 \%$ of the basin area. A high visual similarity between temperature and NDVI was observed, i.e., in areas with lower vegetative index (0.184 to -0.896$)$ the highest temperatures $\left(26.4{ }^{\circ} \mathrm{C}\right.$ to $\left.39^{\circ} \mathrm{C}\right)$ were observed. It was found that the temperature of the soil surface is directly related to the vegetation of the environment.
\end{abstract}

Keywords: burning; deforestation; fire risk. 